\title{
Shadow Play: Patrick Modiano and the Legacy of the Holocaust ${ }^{1}$
}

\section{ALAN MORRIS}

As might be expected of a Nobel Prize winner, Patrick Modiano stands out from the crowd. His $œ u v r e$ is highly personal, and highly literary, thanks to its distinctive interplay of "fiction et diction" (Genette 2004). With each successive text, the same basic universe returns, albeit with slight variations. Typically, an autodiegetic narrator — the novelist's ludically fictionalised, and sometimes autofictional, alter ego — embarks on a quest back into the past, because a now-distant event, or an abiding mystery, continues to impact upon the present. Revisiting once familiar sites (usually in Paris), this protagonist recalls (or occasionally imagines) old experiences, and seeks to preserve, through writing, the little that can still be saved from oblivion. Themes such as identity, difference, loss, remembrance, and forgetfulness predominate; characters and character types recur; a plethora of genres (biography, the historical novel, the roman noir, the love story, amongst others) intermingle; there is a constant va-et-vient between the real and the invented; and temporal levels collapse into a "présent éternel" (mirroring the workings of memory). Stylistically, a self-aware use of intertexts shows that literary creativity subtends the retrospection; the narrative combines with a meta-narrative, undermining any suspension of disbelief; and circularity proliferates, all of which reinforces the lack of final resolution, and ensures that each text is irrevocably non-totalising. Incapable of being shoehorned into established categories, l'œuvre modianesque is, in a word, unique.

Against this general backdrop, the present article will explore Modiano's relationship to the Holocaust, in order to situate him vis-à-vis his peers, the members of "the second generation" or "those who come after" the Shoah, ${ }^{2}$ and to assess the extent to which he falls 
into, or remains detached from, this recognisable group of writers. More particularly, the analysis which follows will have three broad centres of attention: firstly, Modiano's family background; secondly, his writing; and finally, the question of how well or how poorly his writing reflects the Nazis's attempted genocide. However, not all of his texts will be considered. He currently has a total of twenty-eight major works behind him, so the spotlight will be trained principally, but by no means entirely, on the two parts of his $e u v r e$ which seem to reveal most about his treatment of the Holocaust, that is to say his first three novels and Dora Bruder. From this targeted, but non-exclusive, focus, it will emerge that, in his depiction of World War Two, Modiano's aforementioned uniqueness is once again to the fore. He will be seen to be a second-generation, post-Shoah novelist who is haunted by the Occupation, but who, on the whole, and with the glaring exception of Dora Bruder, barely talks about the Holocaust at all.

At first glance, Patrick Modiano appears to be a typical author "who comes after," for he too is marked by the belatedness and the legacy of absence that commentators such as Marianne Hirsch and Eva Hoffman (on the second generation), and Susan Rubin Suleiman (on the 1.5 generation), see as characteristic of these writers. Born on 30 July 1945, of a Belgian, Flemish-speaking actress (Luisa Colpeyn) and a Paris-born Sephardic Jew (Albert Modiano), he did not live through the war years, so experiences them as a hole. Yet as he discloses in his most profoundly autobiographical text, Un pedigree, he believes these years, and especially the unwholesome period of the Occupation, to be fundamental to his inheritance: "le terreau - ou le fumier - d'où je suis issu" (20).

Unlike many mothers and fathers of "those who come after," Albert Modiano was not deported during the war, but this did not mean that, as he was growing up, Patrick had firsthand sources to inform him about the early 1940s. He was neglected by his parents, and regularly entrusted to a host of other people and to boarding schools all over France (from 
which he would often run away). ${ }^{3}$ This sense of solitude and upheaval was subsequently increased by an event that was to taint his life and his future writing — the death of his younger brother, Rudy. Much could be said — and has been said — about the loss of Rudy and its centrality for the $2 u v r e$ modianienne, ${ }^{4}$ but the emphasis here will instead be on the more directly pertinent void associated with Albert.

Troublingly for Modiano, if his father's absence caused problems for him, then things were hardly better when he was present. He was not particularly talkative, and, like so many other survivors (Hoffman 10, 58, 67, 207, 252), he was strikingly more taciturn where the war was concerned. Indicative of this is a visit to the cinema in the late 1950s, to see a documentary called Le Procès de Nuremburg. Patrick was indelibly marked: "Je découvre à treize ans les images des camps d'extermination. Quelque chose a changé, pour moi, ce jourlà" (Un pedigree 57). Albert, however, still said nothing. When he split with his family in the 1960s, then moved to Switzerland, where he died in 1977, "il a emporté ses secrets avec lui" (Un pedigree 20$)$.

In more ways than one, then, and although neither parent was sent to a death camp, Modiano's position is essentially that of the second-generation writers. To reapply Erin McGlothlin's expression, he too is "forever cut off from the meaning of a past event that grounds [his] present life" (2).

This assertion notwithstanding, there are also aspects of Modiano's situation which pull in the opposite direction, and which problematise his status. For example, very strictly speaking, he is not actually Jewish, as there is no matrilineal descent. On top of that, he was baptised when he was five and attended catechism classes. The position and the actions of his father during the Occupation additionally complicate the issue. Whilst Albert avoided the death camps, things could have unfolded very differently. He was arrested twice, but managed to escape the first time, and was then later freed thanks to a contact who was 
possibly — and disturbingly — a French auxiliary of the Gestapo. The explanation of this strange connection may lie in the fact that Albert was active on the black market, where he often mingled with his nominal enemies, thereby becoming the very embodiment of the moral uncertainties of the time.

Erin McGlothlin (14) has pointed up two contrasting second-generation responses to the Holocaust: the first, the works of the surviving sons and daughters of Jewish victims, and the second, texts by the children of Nazi perpetrators of the persecution, grouped under the banner of Väterliteratur (Väter explicitly signalling the role of fathers). As may by now be apparent, Albert Modiano is a Jew and a collaborator, a victim (though not a camp survivor) and, at least complicitly, a perpetrator, so Patrick can be said, to a certain degree, and with a multi-layered ambiguity that is probably unique amongst his peers, to belong to both categories. This is no doubt why he has revealed: "Mon père a pu préserver sa vie grâce à une attitude trouble [...]. Ce qui alimente mon obsession, ce n'est pas Auschwitz, mais le fait que [...] certaines personnes ont pactisé avec leurs bourreaux" (Texier 8).

This obsession is all-pervasive in Modiano's first three novels, La Place de l'Étoile, La Ronde de nuit and Les Boulevards de ceinture, which constitute a very informal "Occupation trilogy." 5

If, as a child, Modiano showed few external signs of being Jewish, La Place de l'Étoile demonstrates that, as an adult, he fully assumes this aspect of his inheritance. The novel is a darkly humorous exploration of Franco-Jewish identity, and its central character, Raphaël Schlemilovitch, theatrically lives a number of alternative lives, and dies on multiple occasions. Like the form of the text — a phantasmagoria in which people, places and epochs merge, composed of different generic conventions, pastiches, historical references and intertextual allusions — he is a mosaic. He is the clichéd Jew incarnate, provocatively moulding himself from the words, actions and experiences of Jews and anti-Semites who 
have preceded him. For example, aware that, during the Occupation, real-life Jews (including Albert Modiano) fraternised with their apparent enemies, he goes through a "Jewish collaborator" phase. The selfsame ambiguity marks his relationship to the Holocaust, encapsulated when he visits Vienna's Prater amusement park, for there, the notionally appealing attractions act out the horrors of the death camps. The "rivière enchantée" leads to "une balle dans la nuque;" the non-stop merry-go-round generates "des monceaux de cadavres," and the lucky bags on sale contain cyanide (112-13). Philippe Zard is certainly right to talk of "la carnavalisation de la mémoire" in this text (in Julien 69-86).

La Ronde de nuit is another expressionistic performance (Blanckeman 60), and similarly has ambiguity at its heart. Centred on the Occupation, its narrator works for both the French Gestapo and the Resistance, and because each side has asked him to infiltrate and betray the other, he is constantly — and self-destructively — out of kilter with himself. His entangled identity is mirrored by the novel's form. Repetition and circularity abound; historical allusions blur the boundary between reality and fiction; intertextual borrowings bolster the sense of "self and other;" chronology is abandoned, and different times are virtually indistinguishable. In the final pages, the death of the protagonist — ludically incongruous for an énonciateur apparently recalling his past — seems to be imminent. The possibility that his memories might therefore be imagined suggests the enduring, burdensome legacy of the war years, still experienced after the event as a hallucinatory nightmare.

Les Boulevards de ceinture marks a break with the frenzy of the two previous novels. Now, in an extended rêverie - characterised again by circles, reflections, and the confusion of temporal levels - the narrator mentally journeys back beyond his birth to the Occupation. His aim is to "connaître ses origins" (137), to stand shoulder to shoulder with his Jewish father, amidst the group of often overtly anti-Semitic collaborators with whom he associates. By fancifully "remembering" their "shared" experiences, he can overcome the paternal 
silence bequeathed. "On s'intéresse à un homme, disparu depuis longtemps," he confides. “[...] Sur ce qu'a été sa vie, on ne possède que de très vagues indications souvent contradictoires [...]. Alors il ne reste plus qu'à imaginer. Je ferme les yeux" (148). The fictionalised mise en scène of Modiano's own relationship with Albert is evident here, as is his interest in the corrosive nature of Time and the difficulty of objectively reconstructing the past. This latter problem is emphasised by a number of self-aware strategies. Photographs are brought to life; scenes drift in and out of focus; light fades and returns; and voices sound like a slowed-down record. No sure knowledge can result from such self-erasing onirisme, but the lure of the Albert-war nexus is glaring.

Taken together, these three works reaffirm that Modiano is less interested in Auschwitz than in the Occupation and the moral complexity that attaches to it. ${ }^{6}$ Despite the specific, but limited, references in La Place de l'Étoile and the recurrence of Jewish father figures during the war years, "none of these texts [... could] be described as Holocaust narratives if we use as a working definition those narratives where the Holocaust and its victims form an explicit, or at least a major, narrative theme" (Damamme-Gilbert 47).

Nevertheless, Modiano is not completely isolated from second-generation writers, for ultimately, in his "trilogy," he too is focusing on his Jewish parent's wartime experiences. More than that, he is putting himself in his father's shoes during the Occupation. "Identification with the positions of both victim and perpetrator is common in narratives by the children of survivors," McGlothlin has noted (28), but Modiano's background gives him far greater cause for this double identification. Little wonder, then, that his first three narrators are all victimes and bourreaux. On the one hand, they embody a sense of solidarity with Albert, as in La Place de l'Étoile, where, through pastiche and by turning racist remarks back on those who expressed them, Modiano offers a linguistic riposte to the anti-Semites: "Je me mets à la place de mon père. Il était muet devant [les antisémites ..., ] il ne pouvait pas 
répliquer, il n'avait pas les armes" (Brunn 10). Yet on the other hand, there is a negative impact on the son. In his first two novels, Modiano has admitted: "Il y a une culpabilisation du fils qui endosse la veulerie du père, son comportement pendant l'occupation" (Texier 8), the result of which, in the author's own words again, is "un certain remords par personne interposée" (Libermann 3). This sense of having somehow aided and abetted (which no doubt feeds into a prime leitmotif of Modiano's work — the narrator in a police van with his father) seems to correspond perfectly to the "notion of inherited guilt" that McGlothlin has discerned. "For the second generation on the side of the perpetrators," she explains, "guilt is [...] connected with the parents' own refusal to admit responsibility for their complicity in the genocide of the Jews [...]. The parents' rejection of guilt, which takes the form of amnesia, is thus passed down to the children, who inherit it as their own burden to bear" (2425). The bequeathing of such a burden seems to lead, in turn, to another strand within the "trilogy" — the wish to be free of the father's war legacy. "L'affaire se situe entre mon père et moi," the author has confided (Texier 8), so there is a certain resonance here with the “early, Oedipal impulses" which permeate second-generation writing (Hoffman 70).

Indeed, the form of each text in Modiano's “trilogy” further suggests a Freudian response to the narrators's, and their creator's, ambiguous roles as (the sons of) victims/perpetrators. As already seen, in his first three novels, Modiano fractures the traditional elements of the genre (chronology, character, linearity, narrative completion, logic and so on), and fashions a dream-like, if not hallucinatory atmosphere. When considered alongside the reappearance of characters, themes and obsessive images, this strategy could be interpreted as indicative of intense trauma, the expression of a compulsion to repeat.

In fact, despite its self-aware humour, the end of La Place de l'Étoile seems to encourage just such an inference. Raphaël, haunted by his memories of the Holocaust, is 
being treated by Sigmund Freud. Freud's reaction is worthy of note. "Comment se fait-il que vous vous rappeliez tout cela," he observes, “vous n'étiez pas né” (150).

The significance of this was alluded to by Modiano in his Nobel acceptance speech. In a passage that additionally exhibits his link to the second-generation writers, he declared:

Je suis $[\ldots]$ un enfant $[\ldots$ du] Paris de l'Occupation. Les personnes qui ont vécu dans ce Paris-là ont voulu très vite l'oublier [...]. Et lorsque leurs enfants les interrogeaient plus tard sur cette période et sur ce Paris-là, leurs réponses étaient évasives, ou bien ils gardaient le silence. Mais devant les silences de nos parents, nous avons tout deviné, comme si nous l'avions vécu. (Discours à l'Académie suédoise 13-14)

"Comme si nous l'avions vécu" — this is the telling phrase, because at the start of his career, confronted by Albert's silence, Modiano, is making this state of mind a key driver of his fiction. As he wrote in 1976 after interviewing Emmanuel Berl, his symbolic — and significantly supportive — Jewish "ancestor": "Il m'encourage dans mon dessein: me créer un passé et une mémoire avec le passé et la mémoire des autres" (Berl 9). The following year, this aim was explicitly reflected in Livret de famille, where the narrator insists:

Ma mémoire précédait ma naissance. J'étais sûr, par exemple, d'avoir vécu dans le Paris de l'Occupation puisque je me souvenais de certains personnages de cette époque et de détails infimes et troublants, de ceux qu'aucun livre d'histoire ne mentionne. Pourtant, j'essayais de lutter contre la pesanteur qui me tirait en arrière, et rêvais de me délivrer d'une mémoire empoisonnée. (96) ${ }^{7}$ 
This ambiguous movement both towards and away from the Occupation and recollection of it — a movement stemming no doubt from Modiano's ambivalent status as the son of a victim/perpetrator - patently resonates with the twofold pull that characterises the second generation's relationship to the Holocaust: wanting, or feeling a duty, to remember whilst wishing, or needing, to forget. There is another notable link here besides. Modiano (behind his autofictional narrator) seems to have fabricated a memory for himself so successfully that it is as if he had lived the wartime life of one or both parents.

What all of this shows is that Modiano is engaging in what Marianne Hirsch has defined as postmemory, 'the relationship that the 'generation after' bears to the $[\ldots]$ trauma of those who came before - to experiences [...] transmitted to them so deeply and affectively as to seem to constitute memories in their own right. Postmemory's connection to the past is thus actually mediated not by recall but by imaginative investment, projection, and creation" (The Generation of Postmemory 5 - original italics). As Hirsch's title here implies, such a postmemorial response from Modiano shows him, once again, to be very much in tune with his second-generation peers.

Towards the end of Les Boulevards de ceinture, Modiano writes that the work will be "le dernier concernant [s]on autre vie" (162), and he was very much true to his word. His next novel, Villa triste, looks back barely any further than the 1960s (even if there are two brief mentions of a Resistance hero $(99,160))$. Thereafter in the euvre, although the Occupation and the father figure's role in it regularly appear, they never again have the preeminence they had in the "trilogy."

In a number of texts, there are direct, if limited, references to the Shoah and the processes linked to it (Livret de famille 105-6; De si braves garçons 129; Rue de boutiques obscures 143, 181-83; Remise de peine 116-17; Voyage de noces 154; Fleurs de ruine 48, 103, 111-12; Chien de printemps 19; Un pedigree 17, 28-29, 101). Sometimes, Albert's two 
arrests — and escapes — are described. Sometimes, the different stages of deportation from Paris are indicated — the identity checks; the rafles; the headquarters of the Police des Questions juives, rue Greffuhle; the rue des Saussaies and the Gestapo; the Magasins Généraux or the Dépôt; Drancy and other internment camps; and finally the convoys east. Sometimes — very rarely — there is an actual mention of deportation and death, such as that of Francis Jansen, a homonym of the father figure in Chien de printemps, who was "arrestato a Roma. Detenuto a Roma, Fossoli campo. Deportato da Fossoli il 26 giugno 1944. Deceduto in luogo e data ignoti" (120). ${ }^{8}$

More often than not, however, in Modiano's works from Villa triste onwards the presence of the Holocaust is only implicit. This subtlety can perhaps best be seen in the use of symbolic animals — dogs (Livret de famille 154), which hark back to the "six millions de chiens" of La Place de l'Étoile (114), but principally horses, whose ultimate destinations are abattoirs (Memory Lane 36; Des inconnues 107, 114, 118-19, 132; La Petite Bijou 149). Alongside these distinctive metaphors, Modiano continues to highlight notions that Hirsch and, particularly, Hoffman have shown to be characteristic of second-generation writing. Some of these, such as the visibility of dysfunctional families, the role of postmemory and the living of an "autre vie," the concern with identity, and the foregrounding of contradictions and ambiguity have already been seen to be present in the "trilogy." Others include the insistent, broadly melancholic focus on exile and loss, suggestively rendered by the prevalence of empty dwellings, and by the vanishing of the narrators's love interests, a recurrent disappearance whose metaphorical links to the Holocaust (and to the death of Rudy) have been demonstrated by France Grenaudier-Klijn (245, 257-58, 266-67). Modiano's liking for the detective-novel format similarly generates "second-generation" themes: the importance of traces; a haunting (or nightmarish) past relived — and compulsively repeated — through flashbacks; the (largely unstated) need to be free of this past and to make things 
return to normal (via an obsessive, retrospective probing); the ongoing impact of a previous crime or accident, which gave rise, like the loss of the narrators's loved ones, to a "cassure" (Vestiaire de l'enfance 134); and the guilt and the need to "rendre des comptes" which attach to this perturbing incident (Vestiaire de l'enfance 48; Fleurs de ruine 112-13). Mention must likewise be made of the motif of "The Return," well illustrated by Dekker/Guise's "pilgrimage" (Quartier perdu), by the theme of "l'éternel retour" (in, say, Accident nocturne, Dans le café de la jeunesse perdu and Souvenirs dormants), and, more generally, by the temporal, rather than spatial, reconnection with a life lived avant le deluge (a sort of paradis perdu), the paradigm of which is the Orphic narrative subtext (Modiano's protagonists tend creatively to relive a past romance, but the lost love ultimately remains lost). Finally, there is the ubiquity of "fantômes," as epitomised by Maillot in Quartier perdu, and the regular disfigurement of characters, usually by scars (Grenaudier-Klijn 83-104). These disfigurements are emblems of a past trauma still visible in the present, and they recall "the trope of marking" which McGlothlin detected in works by the children of survivors and perpetrators alike (20), and which other specialists have also seen as significant (Hoffman 34; Hirsch, The Generation of Postmemory 80).

The same allusiveness is evident in the form of Modiano's writing after Les Boulevards de ceinture. His more mature style is increasingly pared down, minimalistic, and punctuated by gaps that convey a sense of fragmentation and emptiness. Whole sections of the past have disappeared, and the narrative fails comprehensively to link the traces that survive. These devices, along with the interplay between a host of polar opposites (remembrance/amnesia, presence/absence, real/invented, and the like), help to generate a selfdestructive "écriture pénélopienne, qui se développe en se défaisant elle-même" (Blanckeman 22). Modiano's overall approach, therefore, “rappelle la stratégie du détour propre à Elie 
Wiesel, écrivain lui-même hanté par la Shoah: [...] parler d'autre chose. Parler d'autre chose, c'est ne parler que de cette chose mais sans la nommer"' (Blanckeman 67).

Amongst these later works, there is one text which stands out where the portrayal of the Shoah is concerned: Dora Bruder. The eponymous heroine is a real Jewish teenager who died in Auschwitz, and the references to the process of deportation here are plentiful and explicit. Yet Modiano remains atypical of second-generation authors. The Dora he depicts is not a family member, so the narrative "complicate[s] the model of parent-child conveyance of the Holocaust past" (McGlothlin 36).

Anomalous within its peer setting or not, Dora Bruder is quintessentially modianien, a perfect exemplar of the author's more mature texts. The narrative focuses on an investigation of the past, ranging through memory, loss, and forgetfulness, and — in an unspoken recognition of the creative input that Hirsch saw as indispensable for post-Shoah authors - foregrounding the importance of writing, literature and imagination. The search is initiated when Modiano, casting himself as writer-protagonist, discovers an avis de recherche in a newspaper from 1941, which reveals that a certain Dora Bruder has run away from home. Armed with this potted biography (a mise en abyme of the profile to come), he sets off in pursuit of the girl, trying to reconstruct her life, and hence thwart not only the Nazis, who wanted to erase all trace of her as she was Jewish, but also the "sentinelles de l'oubli" (18) who, ever since the war ended, have sought to foster amnesia. As in a traditional detective story, the recreation of the past goes hand in hand with a (meta-)description of how the later investigation proceeds, the key to both of these thrusts being documentation. The narrator of Vestiaire de l'enfance had earlier yearned to "ne plus écrire, mais recopier" (67), and this degree-zero approach is in large part the one adopted in Dora Bruder. In another strategy that is typical of second-generation writing (Schulte Nordholt 225), a plethora of real-life documents are transcribed. Similarly, descriptions of actual photographs - those other 
"fragments of stories, never stories in themselves" (Hirsch, Family Frames 83) — are provided, thereby linking past and present, and life and death within the narrative. Insofar as these "meta-photographic texts" act as "ghostly revenants" (Hirsch, Family Frames 8, 22 respectively), they provide further evidence of the spectral element in Modiano's writing. Despite this documentary raw material, the past that Modiano finally reconstructs remains, as ever in his æeuvre, far from complete. This inconclusive outcome, which chimes with the ethical imperative not to portray the Shoah in its entirety, simultaneously symbolises the broader problem noted by analysts such as Levi and Rothberg (1-2) — the apparent impossibility of ever fully comprehending the Holocaust. Nevertheless, undaunted, the narrator of Dora Bruder attempts to bridge the gap by supplementing his research with alternative sources of information. For instance, believing, like Modiano (Discours à l'Académie suédoise 26), that locations have a palimpsestic quality, conserving the imprints of people and things, he consults the buildings of the informal archive that the city represents. As he reads the urban infrastructure, his physical journey around the capital coincides with his mental journey back through time (and places, as prompts for memories, are as vital for Modiano as they are for second-generation authors globally). However, in many cases, the sites which formed the backdrop to Dora's life — one of which might have been the meaningful "impasse des Chiens" (36) — have also disappeared.

Linked to this strategy, the narrator/Modiano draws on his own experience to help understand Dora, especially regarding the attraction of fugues. This identification with his subject (and with Albert in the text as well) produces a typically modianesque result - past and present become superimposed, the implication perhaps being that: "For the inheritors of traumatic historical experience, the ability to separate the past from the present - to see the past $a$ s the past is a difficult [...] achievement" (Hoffman 279 — original italics). 
The third alternative source of information is literature, in its broadest sense. Throughout Dora Bruder, Modiano helps fill in gaps by hypothesising, in an approach reminiscent of the one he articulated in Livret de famille: "mon dossier était bien mince, mais [... il] suffisait de rêver sur les deux ou trois éléments dont je disposais, et je parviendrais à restituer le reste, comme l'archéologue qui, en présence d'une statue aux trois quarts mutilée, la recompose intégralement dans sa tête" (155). At the same time, again to augment his narrative, he resorts to intertextuality (which adds more "ghostly" presence-and-absence to the work). Momentarily, the text seems to overlap with Hugo's Les Misérables (52-53). There is a clear allusion to Dante: "ici il faut laisser toute espérance" (125). Reference is made to a variety of authors, including Genet and Poe. There is even a mention of one of Modiano's earlier novels, Voyage de noces, in which he dealt with Dora's story fictionally, a self-citation which, in Dora Bruder, forms part of his "self-reflective, metatextual commentary on his own position as a writer" (Damamme-Gilbert 59).

These literary borrowings notwithstanding, the most important intertext of all is the work of Serge Klarsfeld, and especially Le Mémorial de la déportation des Juifs de France. This pioneering study recorded publicly, for the first time, the identities of the deportees in every convoy to leave France for the death camps. Dora and her parents featured there, of course, and the details that Modiano gives of their deportation $(55,146)$ show that he consulted the Mémorial's lists. Furthermore, Klarsfeld became directly involved in Modiano's project (although Dora Bruder fails to acknowledge his contribution, which severely strained their relationship). It was he who unearthed the photographs of Dora and her family, and he who found many of the documents relating to the Bruders; but above all, it was he who served as an inspiration. "Le Mémorial rejoignait [...] certains thèmes que je portais en moi depuis longtemps," Modiano has admitted, “[...] comme la disparition, le thème de l'anonymat des êtres [...,] une précision très ponctuelle, entourée d'un immense 
néant" (Heck 42). Not for nothing, then, did he affirm: "J'ai voulu suivre l'exemple que m’avait donné Klarsfeld” (“Avec Klarsfeld” 8).

All of these points demonstrate that Dora Bruder is a hybrid, a fragmented collage of different, often incompatible genres. It is part biography, part autobiography; part documented investigation, part fiction; part narrative and - again typically for secondgeneration writing (Schulte Nordholt 38) — part self-reflexive meta-narrative. Yet ultimately, as noted above, this all-embracing approach does not fully delineate Dora, and the work itself openly broadcasts this. Blank spaces proliferate throughout, so visually, the lacunae in Dora's life story — her narrative - are impossible to ignore. In much the same way, the intertextual references transport the reader into an extradiegetic hors-texte in search of the work's full "meaning," and thereby further ensure that it is non-totalising. Fittingly, this incompletion is especially noticeable in the concluding paragraphs, because the narrator still cannot say where Dora was when she went missing. Even in the work as a whole, she is rather like an insubstantial spectre (another example of ghostliness), there in the narrative past, but not in the narrative present. Like the "meta-photographic texts" of her that Modiano places en abyme, she is a snapshot of her real self, in the sense that "a photograph is both a pseudo-presence and a token of absence" (Sontag 16).

This lack of full resolution is significant. The "absence" of the central character; the fragmentation; the generic codes that undermine each other; the gaps; the sense of loss; the intertextuality - all of these devices help Modiano to achieve the specific aim of his more mature writing. "L’absence est un état que j'essaie d'exprimer," he has confessed (Cerf 38), or, as he put it in Chien de printemps, his goal — a typically ambiguous one — is to "créer le silence avec des mots" (21). Needless to say, this formal approach is an ideal strategy for evoking the Holocaust, that "incommunicable experience largely made up of void, absence and erasure" (Damamme-Gilbert 46). 
Be that as it may, Dora Bruder is not a totally negative work. The more it progresses, the more the focus slips from Dora herself (a further sign of her "absence" from the text) onto other real-life deportees. Dora comes to represent all of the Jews killed by the Nazis (an additional clue that the incomplete depiction of her life symbolises the "unknowability" of the Holocaust in its entirety), so by seeking to rescue her from oblivion, and by identifying so manifestly with her, Modiano can demonstrate "a second-generation sense of solidarity" (McGlothlin 138) with all the victims (including Albert).

Similarly, by imposing her (and their) presence, he can engage in an act of commemoration. Indeed, Dora Bruder could be interpreted as an emblematic lieu de mémoire. The inventor of this concept, Pierre Nora, has, admittedly, conceded that his analysis does not deal with the sort of unsavoury memories that Dora's story represents (III.1: 19), but on $1^{\text {st }}$ June 2015 , the pertinence of this contention was notably strengthened, as a Promenade Dora Bruder was inaugurated in Paris. Modiano, naturally, took part in the ceremony. Not only that; on the new plaque de rue, there is a transcription of the avis de recherche, with the reference: “in Dora Bruder - Patrick Modiano 1997." Given that street names are themselves iconic forms of memorialisation (a chapter is devoted to them in Nora's seminal survey), what better indication could there be of the impact of Modiano's text, as well as the vital role it has played — and is still playing — in commemorating the Shoah?

In conclusion, as has been shown, Modiano does not fit perfectly into the established mould of the second-generation Holocaust writer. In terms of his family background, his key parent - his Jewish father — is both a victim and, by complicit association, a perpetrator. Because of this, the focus in the auvre tends, on the whole, although Dora Bruder is an obvious exception, to be on the Occupation and its ambiguities, rather than on deportation and the death camps explicitly. 
That said, there is much in Modiano's writing that does chime with the work of "those born after," albeit implicitly. Particularly striking here is the recourse to postmemory in the early novels, and the consequent movement both towards and away from the pre-natal life created. Then there are the frequently intertwined leitmotifs: dysfunctional families and problematic identities; exile and return; crime and guilt; "cassure" and marking; and the need to escape. No less resonant than these aspects of his content are Modiano's formal choices. Initially, these result in the swirling, illogical dreamscapes of the Occupation "trilogy," where everything, including characters and temporal levels, seems to merge into a confused mass. Subsequently, they lead to the more mature style exemplified by Dora Bruder, where the texts themselves convey the silence that lies at their hearts.

In this context, and bearing in mind that all commentators on the Holocaust agree that finding a suitable way to represent it is a fundamental concern, the words of Erin McGlothlin, referencing Geoffrey Hartman, are most eloquent:

The second generation's attempt to imagine its parents' past results in a narrative crisis in which narrative voice fractures, protagonists multiply in a compulsion to repeat, temporality is suspended, and generic conventions are transgressed or radically reshaped. These narrative transgressions $[\ldots]$ are textual wounds $[\ldots]$. The writing of the second generation functions as a residue of this marking of Holocaust legacy, which leaves its traces in the process of writing rather than revealing the full presence of the event. (12-13 - my italics)

“The crux of the second generation's difficulty [is] that it has inherited not experience, but its shadows," Eva Hoffman has asserted (66), and Modiano might be said to convey precisely this sentiment in his (often spectral) work. At first glance, he seems largely to 
ignore the Nazis's attempted genocide, barely acknowledging it visibly. Yet deep down, in his "diction" rather than his "fiction," he subtly does the exact opposite. He lays bare the wounds bequeathed, and expresses paradigmatically the traumatic inheritance of "those who come after." In short, he takes as his own the telling phrase by Stendhal, which he quoted in Pour que tu ne te perdes pas dans le quartier: "Je ne puis pas donner la réalité des faits, je n'en puis présenter que l'ombre" (9 - original italics).

\section{University of Strathclyde}

\section{Notes}

1. This article began life as a presentation to the workshop on "The Holocaust in French Literature," held at The Holocaust Research Institute, Royal Holloway, University of London, on 9 June 2017.

2. My approach to naming the tragedy echoes that of Eva Hoffman: "I use the terms 'Holocaust' [... and] 'Shoah' [...] interchangeably, as they have come to be used in both colloquial and scholarly discourse" (xiv).

3. These biographical details are regularly evoked in his novels. See, for example, Remise de peine, De si braves garçons, and Fleurs de ruine.

4. See notably Laurent, 121-33.

5. When the English translations of each novel were published together in one volume, the title chosen was, precisely, The Occupation Trilogy.

6. For an in-depth study of the Occupation in Modiano's fiction, see Roux 1999.

7. As in La Place de l'Étoile, this anamnesis later elicits the comment: "Mais comment le saviez-vous? Vous n'étiez pas né" (119).

8. Significantly, four of Albert's cousins were killed in Italy by the SS in 1943 (Un pedigree 13-14). 


\section{Works Cited}

All books are published in Paris unless otherwise indicated

Berl, Emmanuel. "Interrogatoire par Patrick Modiano” suivi de "Il fait beau, allons au cimetière." Gallimard, 1976.

Blanckeman, Bruno. Lire Patrick Modiano. Colin, 2009.

Brunn, Julien. "Patrick Modiano: Exilé de quelque chose.” Libération 22 Sept. 1975: 10.

Cerf, Juliette. “« Découvrir qui je suis ne m'intéresse pas ».” Le Magazine Littéraire, HS 2, Oct. 2014: 36-40.

Damamme-Gilbert, Béatrice. "The Question of Genre in Holocaust Narrative: The Case of Patrick Modiano’s Dora Bruder.” Genre Trajectories: Identifying, Mapping, Projecting. Ed. Gavin Dowd and Natalya Rulyova. Basingstoke; New York: Palgrave Macmillan, 2015. 45-65.

Genette, Gérard. Fiction et Diction. 1979. Éditions du Seuil, 2004

Grenaudier-Klijn, France. La Part du féminin dans l'œuvre de Patrick Modiano: Fonctions et attributs des personnages féminins modianiens. L'Harmattan, 2017.

Heck, Maryline. “« J'aurais pu croire que la boucle était bouclée, mais... ».” Le Magazine Littéraire, HS 2, Oct. 2014: 40-44.

Hirsch, Marianne. Family Frames: Photography, Narrative and Postmemory. 1997.

Cambridge, Mass.; London: Harvard University Press, 2012.

—. The Generation of Postmemory: Writing and Visual Culture after the Holocaust.

New York; Chichester: Columbia University Press, 2012.

Hoffman, Eva. After Such Knowledge: A Meditation on the Aftermath of the Holocaust. 2004. London: Vintage, 2005. 
Julien, Anne-Yvonne, ed. Modiano ou les intermittences de la mémoire. Hermann, 2010.

Klarsfeld, Serge. Le Mémorial de la déportation des Juifs de France. Klarsfeld, 1978.

Laurent, Thierry. L'Euvre de Patrick Modiano: Une autofiction. Lyon: Presses universitaires de Lyon, 1997.

Levi, Neil and Michael Rothberg, eds. The Holocaust: Theoretical Readings. Edinburgh: Edinburgh University Press, 2003.

Libermann, Jean. 'Patrick Modiano: Lacombe Lucien n'est pas le portrait du fascisme, mais celui de sa piétaille.” Presse Nouvelle Hebdo 8 Mar. 1974: 3, 9.

McGlothlin, Erin. Second-Generation Holocaust Literature: Legacies of Survival and Perpetration. Rochester NY; Martlesham: Boydell and Brewer, 2006.

Modiano, Patrick. Accident nocturne. Gallimard, 2003

__. “Avec Klarsfeld, contre l'oubli.” Libération 2 Nov. 1994: 8.

—. Les Boulevards de ceinture. Gallimard, 1972.

—. Chien de printemps. Éditions du Seuil, 1993.

—. Dans le café de la jeunesse perdu. Gallimard, 2007

—. De si braves garçons. Gallimard, 1982.

—. Discours à l'Académie suédoise. Gallimard, 2014.

—. Dora Bruder. Gallimard, 1997.

_. Fleurs de ruine. Éditions du Seuil, 1991.

_. Des inconnues. Gallimard, 1999.

_. Livret de famille. Gallimard, 1977.

—. Memory Lane. Hachette, 1981.

—. The Occupation Trilogy. London: Bloomsbury, 2015

- Un pedigree. Gallimard, 2005.

_ L La Petite Bijou. Gallimard, 2001. 
_. La Place de l'Étoile. Gallimard, 1968.

_. Pour que tu ne te perdes pas dans le quartier. Gallimard, 2014.

—. Quartier perdu. Gallimard, 1984.

—. Remise de peine. Éditions du Seuil, 1988.

—. La Ronde de nuit. Gallimard, 1969.

—. Rue de boutiques obscures. Gallimard, 1978.

- Souvenirs dormants. Gallimard, 2017

—. Vestiaire de l'enfance. Gallimard, 1989.

—. Villa triste. Gallimard, 1975.

—. Voyage de noces. Gallimard, 1990.

Nora, Pierre, ed. Les Lieux de mémoire. Gallimard, 1984-1992, 3 vols.

Roux, Baptiste. Figures de l'Occupation dans l'œuvre de Patrick Modiano. Paris; Montreal: L'Harmattan. 1999.

Schulte Nordholt, Annelies. Perec, Modiano, Raczymow: La Génération d'après et la mémoire de la Shoah. Amsterdam; New York: Rodopi, 2008.

Sontag, Susan. On Photography. 1977. Harmondsworth: Penguin, 1979.

Suleiman, Susan Rubin. "The 1.5 Generation: Thinking about Child Survivors and the Holocaust.” American Imago, 59.3 (2002): 277-95.

Texier, Jean-C. "Rencontre avec un jeune romancier: Patrick Modiano.” La Croix 9-10 Nov. 1969: 8 . 